\title{
S Permissions notes
}

The following institutions and individuals gave permission to use the copyrighted poetic texts. Public domain texts and briefly cited texts are not listed.

"Elegiia na rentgenovskii snimok moego cherepa” by Elena Shvarts, courtesy of Kirill Kozyrev.

"Ob"em prevrashchaetsia v ploskost'. Eto i est' smert"' by Polina Barskova, courtesy of the author.

"Fotografiia" by Arsenii Tarkovsky, courtesy of Marina Tarkovskaya.

"Khmel'," Sosny," “Groza, momental'naia navek," "V lesu," "Zerkalo," "Toska, beshenaia, beshenaia," "Zamestitel'nitsa," "Studenty" (Deviat'sot piatyi god), Spektorskii, Doktor Zhivago, and "Edinstvennye dni” by Boris Pasternak, courtesy of the Pasternak Family Estate.

Russian language poems, interview excerpts, and archival materials by Joseph Brodsky used by permission of The Wylie Agency LLC. Translations "We lived in a city the colour of frozen vodka," "Lithuanian Nocturne," "Roman Elegies," "Brise Marine," "A Polar Explorer” by Joseph Brodsky (Collected Poems in English, 2002), and "Christmas Ballad” (Nativity Poems, 2002), trans. Glynn Maxwell are reprinted here by kind permission of Carcanet Press Limited, Manchester, UK and Farrar, Straus and Giroux, Macmillan Publishers, New York, USA. Excerpts from Less Than One, On Grief and Reason, and Watermark used with permission of Farrar, Straus and Giroux, Macmillan Publishers, New York, USA, and Hamish Hamilton, an imprint of Penguin Books Ltd., London, UK.

"Noch' pered vystupleniem," "Snimok," and "Klianus'” by Bella Akhmadulina used with permission of Boris Messerer.

"Sni, kotorye vidiat fotografov," "Ksenii," by Arkadii Dragomoshchenko used with permission of Zinaida Dragomoshchenko. 
"Slomannye fotografii Dzhona Glessi," "Fotobumaga. Strana izgotovleniia-EU," "Na smert' liubogo cheloveka ... ." by Andrei Sen-Sen'kov used with the author's permission.

"menia vsegda udivliaet ..." by Kirill Medvedev used with the author's permission. 